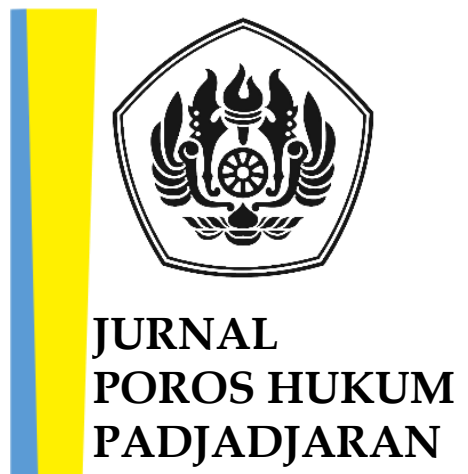

P-ISSN: 2715-7202

E-ISSN: 2715-9418

Artikel diterbitkan: 29 Mei 2020

DOI:

https://doi.org/10.23920/jphp .v1i2.233

Halaman Publikasi:

http://jurnal.fh.unpad.ac.id/i ndex.php/JPHP/issue/archive

Diterbitkan oleh:

Fakultas Hukum

Universitas Padjadjaran

\title{
PAJAK BUMI DAN BANGUNAN YAYASAN PENDIDIKAN DALAM PENGEMBANGAN PENDIDIKAN NASIONAL
}

\section{LAND AND BUILDING TAX ON THE EDUCATIONAL FOUNDATION IN DEVELOPMENT OF NATIONAL EDUCATION}

\author{
Dewi Kania Sugiharti ${ }^{1}$, Faqih Lutfi ${ }^{2}$, Holyness N. Singadimedja ${ }^{3}$
}

\begin{abstract}
ABSTRAK
Yayasan pendidikan merupakan lembaga yang berada di luar pemerintahan dan bersifat non profit oriented, turut terlibat aktif dalam upaya pengembangan pendidikan di Indonesia. UU PDRD memberi kesempatan bagi yayasan pendidikan untuk mendapatkan pengecualian pembayaran Pajak Bumi dan Bangunan Perdesaan dan Perkotaan (PBB-P2). Permasalahan muncul di Kota Bandung setelah adanya kebijakan pengalihan pajak pusat ke daerah dengan pemungutan PBB-P2 terhadap yayasan pendidikan. Metode pendekatan dalam penelitian ini adalah metode yuridis normatif. Data dalam penelitian ini merupakan kombinasi data primer melalui wawancara dan data sekunder melalui studi kepustakaan yang dianalisis secara deskriptif-analisis. Hasil penelitian menunjukkan bahwa tidak adanya kriteria baku dan jelas terkait yayasan pendidikan yang dapat dikenakan pemungutan PBB-P2 dan Implementasi pemungutan PBB-P2 terhadap yayasan pendidikan di Kota Bandung dinilai belum maksimal karena pelaksanaan pemutakhiran data yang dilakukan pemerintah Kota Bandung belum menyeluruh serta minimnya sosialisasi dan komunikasi terkait pemungutan PBB-P2 terhadap yayasan pendidikan dalam kerangka pengembangan pendidikan nasional.
\end{abstract}

Kata kunci: PBB-P2; penerapan; yayasan.

\begin{abstract}
Educational foundations are institutions that are outside the government and are non-profit oriented, actively involved in efforts to develop education in Indonesia. The PDRD Law provides an opportunity for educational foundations to get exemptions from paying the Rural and Urban Land and Building Tax (PBB-P2). Problems arise in the city of Bandung after the policy of transferring the central tax to the regions by collecting PBB-P2 on educational foundations. The approach method in this research is a normative juridical method. The data in this study are a combination of primary data through interviews and secondary data through literature studies that are analyzed descriptively-analysis. The results showed that there were no clear
\end{abstract}

\footnotetext{
1 Fakultas Hukum Universitas Padjadjaran, Jalan Raya Bandung-Sumedang KM.21 Jatinangor Kab. Sumedang, e-mail: dewikaniasugiharti@gmail.com.

2 Program Studi S1 Fakultas Hukum Universitas Padjadjaran Jalan Raya Bandung-Sumedang KM.21 Jatinangor Kab. Sumedang, e-mail: faqihlutfi@gmail.com.

${ }^{3}$ Fakultas Hukum Universitas Padjadjaran, Jalan Raya Bandung-Sumedang KM.21 Jatinangor Kab. Sumedang, e-mail: holyness75.hs@gmail.com.
} 
and standard criteria related to educational foundations that could be subject to PBB-P2 collection and the implementation of PBB-P2 collection of educational foundations in Bandung was considered not optimal because the implementation of updating the data by the Bandung city government was not comprehensive and lack of socialization and communication related to PBB-P2 collection towards educational foundations within the framework of developing national education.

Keywords: foundation; implementation; PBB-P2.

\section{PENDAHULUAN}

Pengelolaan pendidikan di Indonesia tidak hanya menjadi tanggung jawab dari lembaga pemerintah dan kementerian, tapi juga menuntut peran serta lembaga diluar pemerintahan yang juga memiliki tanggung jawab dan diberikan kewenangan oleh UUD 1945 untuk turut serta mengembangkan pendidikan nasional. Undang-Undang Nomor 20 Tahun 2003 tentang Sistem Pendidikan Nasional (selanjutnya disebut UU Sisdiknas) menghendaki keseluruhan komponen pendidikan yang ada di Indonesia harus saling terkait secara terpadu dalam mencapai tujuan pendidikan nasional. Salah satu komponen lembaga di luar pemerintahan yang terlibat dalam membantu menyukseskan pengembangan pendidikan adalah yayasan yang bergerak di bidang pendidikan.

Secara umum dalam periodisasi sejarah, yayasan mulai dikenal dan diakui keberadaanya sejak abad kesembilan belas di Belanda, dengan stichting, yang selanjutnya masuk ke Indonesia sejak Hindia Belanda. ${ }^{4}$ Setiap yayasan termasuk juga diantaranya yayasan pendidikan lazimnya merupakan suatu badan hukum yang bergerak di bidang sosial dan tujuannya bukan untuk mencari keuntungan, melainkan untuk melakukan usaha yang bersifat sosial. Saat ini perkembangan yayasan yang bergerak di bidang pendidikan cukup pesat di Indonesia, sampai tahun 1996 yayasan yang ada di Indonesia adalah kurang lebih berjumlah 3403 (tiga ribu empat ratus tiga). ${ }^{5}$

Setiap yayasan pendidikan hakikatnya memiliki tujuan sosial, salah satunya untuk mewujudkan tujuan negara yaitu mencerdaskan kehidupan bangsa, berdasarkan sifat kesosialan di atas menjadikan yayasan pendidikan sebagai salah satu obyek tidak kena pajak khususnya terkait pajak bumi dan bangunan (selanjutnya disebut PBB) atau dengan kata lain mendapatkan pembebasan PBB. Berdasarkan pada praktiknya, yayasan bidang pendidikan memungut biaya pendidikan kepada siswa yang lazim

\footnotetext{
4 Rochmat Soemitro, (1993). Hukum Perseroan Terbatas, Yayasan dan Wakaf, Bandung: PT. Eresco, hlm. 165.

${ }_{5}$ Chatamarrasjid Ais, (2002). Badan Hukum Yayasan (Suatu Analisis Mengenai Yayasan Sebagi Suatu Badan Hukum Sosial), Bandung: PT. Citra Aditya Bakti, hlm. 5.
} 
disebut Sumbangan Pembinaan Pendidikan (selanjutnya disebut SPP) yang dilakukan untuk memenuhi kebutuhan dana terkait keperluan pembiayaan bersifat administratif. Hasil sumbangan yang dipungut oleh yayasan dari sistem SPP setelah dikurangi oleh pembiayaan yang bersifat administratif terkadang masih menyisakan nominal uang yang tidak sedikit yang dalam yayasan dikenal sebagai sisa lebih yang dapat dikatakan sebagai salah satu keuntungan bagi yayasan. Pada beberapa analisa dan penelitian, sisa lebih yang dimaksud diatas banyak dianggap dan dikategorikan sebagai nilai keuntungan sebuah yayasan yang menghilangkan pemaknaan yayasan pendidikan sebagai lembaga yang bergerak di bidang sosial tanpa memperoleh keuntungan dengan kesengajaan. Stigma ini secara otomatis menghilangkan kategorisasi yayasan pendidikan sebagai bagian dari lembaga pendidikan swasta yang dapat dikecualikan sebagai obyek kena pajak yang dapat dibebaskan dari pembayaran PBB.

Ketentuan pengecualian ini secara jelas diatur dalam Pasal 77 Ayat (3) huruf (b) Undang-Undang Nomor 28 Tahun 2009 tentang Pajak dan Retribusi Daerah (selanjutnya disebut UU PDRD) yang berbunyi:

“digunakan semata-mata untuk melayani kepentingan umum di bidang ibadah, sosial, kesehatan, pendidikan dan kebudayaan nasional, yang tidak dimaksudkan untuk memperoleh keuntungan."

Ketentuan tersebut mengatur secara jelas terkait pengertian serta pembatasan mengenai kegiatan apa saja yang termasuk dalam pengecualian PBB, namun dalam praktiknya tidak semua subyek pajak yang melakukan kegiatan sesuai dengan maksud ketentuan Pasal 77 Ayat (3) huruf (b) dapat dikecualikan untuk tidak membayar PBB termasuk sebagai obyek PBB yang dimaksud adalah bumi dan bangunan dari yayasan pendidikan. Praktik yang terjadi adanya pergeseran maksud dan tujuan yayasan, dari tujuan sosial, keagamaan, dan kemanusiaan ke profit oriented, sehingga pemaknaan sebagai sebuah lembaga nirlaba kemanusiaan dengan kegiatan tidak untuk mencari keuntungan menjadi tidak relevan lagi. ${ }^{6}$

Pasal 286 Ayat (1) Undang-Undang Nomor 23 Tahun 2014 tentang Pemerintahan Daerah (selanjutnya disebut UU Pemda) menjelaskan pelaksanaan penarikan pajak

\footnotetext{
${ }^{6}$ Anwar Borahima, (2000). Kedudukan Yayasan di Indonesia Eksistensi, Tujuan dan Tanggung Jawab Yayasan, Jakarta: Kencana Prenada Media Group, hlm. 153.
} 
daerah dan retribusi dearah yang berbunyi, "Pajak daerah dan retribusi daerah ditetapkan dengan undang-undang yang pelaksanaan di Daerah diatur lebih lanjut dengan Perda."

Lahirnya UU PDRD memberikan ruang kepada daerah untuk melakukan pembatasan dan pengaturan secara mandiri berkaitan dengan pemungutan pajak khususnya PBB melalui instrumen pengaturan mandiri dalam peraturan daerah dan secara teknis peraturan kepala daerah. Secara khusus di Kota Bandung, Pengaturan pajak daerah diatur pada Peraturan Daerah Kota Bandung Nomor 20 Tahun 2011 tentang Pajak Daerah (selanjutnya disebut Perda tentang Pajak Daerah), sedangkan terkait pemungutan PBB di Kota Bandung diatur dalam Peraturan Wali Kota Bandung Nomor 244 Tahun 2017 tentang Petunjuk Teknis dan Tata Cara Pemungutan Pajak Bumi dan Bangunan (selanjutnya disebut Perwal Kota Bandung tentang PBB). Berhubungan dengan pengaturan tersebut diatas, pada tahun 2016 Pemerintah Kota Bandung mulai menerapkan kebijakan pemungutan Pajak Bumi dan Bangunan Perdesaan dan Perkotaan (selanjutnya disebut PBB-P2) bagi lembaga pendidikan swasta yang notebene di tahun-tahun sebelumnya dikecualikan dalam pembayaran PBB-P2. Instrumen kebijakan tersebut dinilai oleh pihak yang berkepentingan langsung cacat hukum dari segi pengaturannya dan tidak memberikan rasa keadilan bagi masyarakat.

\section{METODE PENELITIAN}

Metode pendekatan yang digunakan dalam penelitian ini adalah metode yuridis normatif. Yuridis normatif yaitu metode dimana peraturan perundang-undangan yang diteliti sesuai dengan rumusan masalah, selain itu pula, lebih mengutamakan penelitian kepustakaan serta bagaimana implementasinya dalam praktek. ${ }^{7}$ Spesifikasi penelitian ini adalah deskriptif analistis, dimaksudkan untuk memberikan data yang seteliti mungkin tentang manusia, keadaan atau gejala-gejala lainnya. ${ }^{8}$

Penelitian ini memperoleh data yang bersumber dari penelitian kepustakaan dan penelitian lapangan juga data yang diperoleh melalui wawancara kepada pihak terkait. Analisis data dilakukan secara yuridis kualitatif dengan menjabarkan fakta berdasarkan

\footnotetext{
7 Ronny Hanitjo Soemitro, (1990). Metodologi Penelitian Hukum dan Jurimetri, Jakarta: Ghalia Indonesia, hlm. 97.

8 Soerjono Soekanto, (2014). Pengantar Penelitian Hukum, Jakarta: Penerbit Universitas Indonesia (UI-Press), hlm. 51.
} 
hasil penelitian berupa penjelasan yang tidak berbentuk angka dan kesesuaiannya terhadap ketentuan perundang-undangan beserta asas dan teori yang bersinggungan.

\section{PEMBAHASAN}

Kriteria Pengenaan dan Pengecualian Pajak Bumi dan Bangunan Terhadap Yayasan Bidang Pendidikan

Pajak menurut Rochmat Soemitro adalah iuran rakyat kepada kas negara (peralihan kekayaan dari sektor partikulir ke sektor pemerintah) berdasarkan undangundang (dapat dipaksakan) dengan tiada mendapat jasa timbal (tegen prestasi), yang langsung dapat ditunjukkan dan digunakan untuk membiayai pengeluaran umum, ${ }^{9}$ selain itu terdapat istilah perpajakan, menurut Ensiklopedi Perpajakan yang ditulis oleh Sophar Lumbantoruan, administrasi perpajakan (tax administration) ialah cara-cara atau prosedur pengenaan dan pemungutan pajak. ${ }^{10}$ De Jantscher seperti dikutip Gunadi, menekankan peran penting administrasi perpajakan dengan menuju pada kondisi terkini, kebijakan perpajakan (tax policy) yang dianggap baik (adil dan efisien) dapat saja kurang sukses menghasilkan penerimaan atau mencapai sasaran lainnya karena administrasi perpajakan yang tidak mampu melaksanakannya. ${ }^{11}$ Dasar bagi terwujudnya suatu administrasi pajak yang baik dipengaruhi oleh kebijakan perpajakan yang jelas dan sederhana sehingga memudahkan wajib pajak untuk melaksanakan kewajibannya, tersedianya pegawai pajak yang berkualitas dan jujur, serta pelaksanaan penegakan hukum yang tegas dan konsisten, tidak terkecuali dalam hal pemungutan pajak di daerah, salah satunya ialah PBB-P2.

Melihat instrumen yang ada di Kota Bandung, dasar hukum pemungutan PBB-P2 di Kota Bandung telah mendasarkan pada Perda Tentang Pajak Daerah, Peraturan Wali Kota tentang PBB, serta Standar Operasional Prosedur (SOP). Terkait SOP PBB Kota Bandung mengacu pada hasil wawancara yang dilakukan, aturan teknis dan pelaksanaannya telah diatur dalam Peraturan Wali Kota Bandung yang memuat juga prosedur sebagaimana yang biasanya dikehendaki dalam sebuah SOP.12

\footnotetext{
9 Rochmat Soemitro, (1994). Asas dan Dasar Perpajakan, Bandung: Refika Aditama, hlm. 5.

10 Sophar Lumbantoruan, (1997). Administrasi Perpajakan, Jakarta: Sinar Harapan, hlm. 3.

11 Gunadi. (1995). Peranan Pemeriksaan dan Penyidikan di Era Refromasi dalam Reformasi Perpajakan di Indonesia, Jakarta: Yapnindo, hlm. 17.

12 Maman Juayraman, Kepala Bagian PAD II official asessment Badan Pengelolaan Pendapatan Daerah Kota Bandung, Wawancara Pribadi, Bandung, 16 November 2018.
} 
Memperhatikan pengertian pajak dari Rochmat Soemitro, yang menyebutkan pajak sebagai iuran rakyat kepada kas negara (peralihan kekayaan dari sektor partikulir ke sektor pemerintah) berdasarkan undang-undang (dapat dipaksakan) dengan tiada mendapat timbal jasa (tegen prestasi) secara langsung. ${ }^{13}$ Teori tersebut menjadi salah satu dasar bahwa setiap pemungutan, pengurangan, juga pengecualian PBB memang harus selalu mengacu kepada peraturan perundang-undangan dan aturan tertulis lainnya.

PBB-P2 menjadi salah satu jenis pajak daerah yang menjadi penyumbang Pendapatan Asli Daerah (PAD) terbesar setiap tahunnya di Kota Bandung. Dilihat dari mulai diadakannya pemungutan PBB-P2 pada Tahun 2013 sampai saat ini, Pemerintah Kota Bandung melalui Badan Pengelolaan Pendapatan Daerah (selanjutnya disebut BPPD) selalu mencapai target diatas $90 \%$ (sembilan puluh persen) dalam realisasi pemungutan PBB-P2 setiap tahunnya. Realisasi pemungutan PBB-P2 Kota Bandung pada Tahun 2013 sebesar Rp. 280.104.269.013 (dua ratus delapan puluh miliar, seratus empat juta, dua ratus enam puluh sembilan ribu, tiga belas rupiah) $(101,86 \%$ (seratus satu koma delapan puluh enam persen) pencapaian target), Tahun 2014 sebesar Rp. 372.206.543.770 (tiga ratus tujuh puluh dua miliar, dua ratus enam juta, lima ratus empat puluh tiga ribu, tujuh ratus tujuh puluh rupiah) $(103,39 \%$ (seratus tiga koma tiga puluh sembilan persen) pencapaian target), Tahun 2015 sebesar Rp. 390.800 .914 .079 (tiga ratus sembilan puluh miliar, delapan ratus juta, sembilan ratus empat belas ribu, tujuh puluh sembilan rupiah) $(92,61 \%$ (sembilan puluh dua koma enam puluh satu persen) pencapaian target), Tahun 2016 sebesar Rp. 417.134.044.862 (empat ratus tujuh belas miliar, seratus tiga puluh empat juta, empat puluh empat ribu, delapan ratus enam puluh dua rupiah) (100,51\% (seratus koma lima puluh satu persen) pencapaian target), Tahun 2017 sebesar Rp. 542.756.111.321 (lima ratus empat puluh dua miliar, tujuh ratus lima puluh enam juta, seratus sebelas ribu, tiga ratus dua puluh satu rupiah) $(93,82 \%$ (sembilan puluh tiga koma delapan puluh dua persen) pencapaian target), Tahun 2018 sebesar Rp. 44.689.599.223 (empat puluh empat miliar, enam ratus delapan puluh sembilan juta, lima ratus sembilan puluh sembilan ribu, dua ratus dua puluh tiga rupiah) (6,38\% (enam koma tiga puluh delapan persen) Realisasi per Mei 2018). Keberhasilan pencapaian realisasi PBB-P2 menunjukkan bahwa Pemerintah Kota

${ }^{13}$ Rochmat Soemitro, (1994). Op.Cit. 
Bandung telah melakukan proses pengalihan pajak pusat ke daerah dengan baik khususnya bidang PBB-P2 dan menjadi salah satu penyumbang terbesar PAD.

Ketentuan pasal pada UU PBB yang menjadi dasar dalam pengecualian PBB bagi yayasan saat masih menjadi pajak pusat juga diatur secara limitative dalam UU PDRD terkait obyek pajak yang dapat dikecualikan dalam pengenaan PBB, ketentuan pengecualian tersebut diatur dalam Pasal 77 Ayat (3) huruf b UU PDRD yang berbunyi:

“Objek Pajak yang tidak dikenakan Pajak Bumi dan Bangunan Perdesaan dan Perkotaan adalah objek pajak yang:

b. digunakan semata-mata untuk melayani kepentingan umum di bidang ibadah, sosial, kesehatan, pendidikan dan kebudayaan nasional, yang tidak dimaksudkan untuk memperoleh keuntungan."

Pengalihan PBB-P2 dengan tindak lanjut dikeluarkannya Perda tentang Pajak Daerah, yang secara lebik spesifik dan teknis diatur dalam Perwal Kota Bandung tentang PBB, Pembebasan PBB bagi yayasan pendidikan di Kota Bandung tidak sepenuhnya dijalankan. Proses pengalihan pajak pusat ke pajak daerah menjadi awal mula upaya revolusi perpajakan khususnya PBB di Kota Bandung. Pemerintah Kota Bandung melakukan peninjauan ulang terhadap beberapa yayasan pendidikan yang disinyalir tidak berhak akan pembebasan PBB atau dalam kategori mampu untuk membayar PBB.

Berdasarkan wawancara yang dilakukan oleh penulis, beberapa yayasan pendidikan yang mulai dikenakan penerapan pemungutan PBB di Kota Bandung diantaranya:

1. Yayasan Pendidikan Taruna Bakti yang menaungi pendidikan PAUD, SD, SMP, dan juga SMA.

2. Yayasan Pendidikan Istiqomah yang menaungi pendidikan PAUD, SD, SMP, dan SMA.

3. Yayasan Widyatama Bandung yang menaungi Universitas Widyatama.

4. Yayasan Pendidikan Nasional yang menaungi pendidikan SMP dan SMA.

5. Yayasan Pasundan yang menanungi pendidikan SD, SMP, SMA, dan Universitas.

6. Yayasan BPK Penabur Bandung.

7. Serta beberapa yayasan lain yang ada di Kota Bandung. 
Data terkait yayasan yang dikenakan PBB di atas sangat mungkin untuk bertambah mengingat penulis hanya mewawancara kepada beberapa yayasan secara acak yang ada di Kota Bandung. Pelaksanaan pemungutan PBB terhadap yayasan pendidikan mulai diberlakukan pada Tahun 2016, tiga tahun setelah Pemerintah Kota Bandung melakukan pengalihan Pajak Pusat menjadi Pajak Daerah. Dasar penerapan pemungutan $\mathrm{PBB}$ terhadap yayasan pendidikan dikarenakan yayasan pendidikan tersebut berkegiatan tidak sesuai dengan maksud dan tujuan yayasan dalam AD/ART yaitu tidak untuk mencari keuntungan dan kegiatannya diupayakan tidak untuk melayani kepentingan umum dan meningkatkan kesejahteraan masyarakat.

Pada dasarnya prosedur penilaian yang ditempuh melalui pendekatan pendapatan sebagaimana dilakukan di Kota Bandung adalah memproyeksikan pendapatan yang diperhitungkan dapat dihasilkan oleh suatu properti (yayasan pendidikan) di masa mendatang menjadi nilai saat ini dikurangi beban/biaya/bunga/gaji atau pengeluaran pertahun. ${ }^{14}$ Proses penilaian dengan metode pendekatan pendapatan dilakukan oleh tim teknis yang ditunjuk oleh BPPD untuk mendapatkan data berdasarkan fakta yang objektif dan keyakinan dalam waktu dan relevansi yang otentik. Produk akhir yang dihasilkan oleh tim teknis adalah berwujud pendapat tertulis yang dijadikan patokan bagi BPPD Kota Bandung untuk menetapkan besaran tarif, penetapan pengenaan $\mathrm{PBB}$, bahkan juga pengurangan atau pembebasan PBB bagi yayasan bidang pendidikan. Penulis berpendapat bahwa dasar pendapat tertulis yang dibuat oleh teknis dalam penetapan dan penilaian PBB sangat tidak mewakili frase "nyata-nyata" dalam ketentuan UU PDRD.

Frase "nyata-nyata" dimaksudkan bahwa terhadap menilai suatu obyek pajak tidak cukup hanya dengan menggunakan analisa AD/ART dan laporan keuangan untuk menilai segi keuntungan, tapi juga diperlukan tinjau langsung suatu obyek pajak untuk meyakinkan secara nyata bahwa kegiatan yang dilakukan tidak untuk memperoleh keuntungan. Ketidakterwakilan ini juga disebabkan proses penilaian tersebut hanya berjalan satu arah melalui BPPD, namun pihak yayasan sebagai obyek pengenaan kebijakan tidak diberikan kesempatan pembelaan dengan memberikan data dan penjelasan lain terkait hal berhubungan dengan yayasan pendidikan yang

\footnotetext{
${ }^{14}$ Direktorat Jenderal Pajak Kementerian Keuangan (2014), Buku Pedoman Pengelolaan Pengalihan PBB P2, diakses pada tanggal $18 \quad$ November

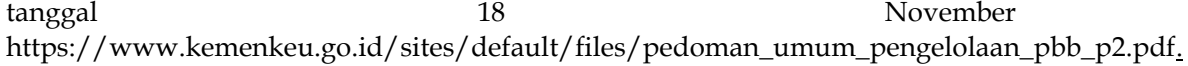
2018.
} 
dijalankan. Upaya kebijakan pengenaan PBB-P2 akan bisa memberikan rasa keadilan dan efektif dengan melibatkan pihak terkait sebagai bagian dari kriteria yang harus dipenuhi untuk juga diberikan akses penyampaian opini dan bukti tandingan dalam kerangka penilaian pemungutan PBB.

Setiap yayasan termasuk juga diantaranya yayasan pendidikan lazimnya merupakan suatu badan hukum yang bergerak di bidang sosial dan tujuannya bukan untuk mencari keuntungan, melainkan untuk melakukan usaha yang bersifat sosial. Kalau memang ditemui suatu yayasan pendidikan kegiatannya secara nyata diupayakan untuk meraih keuntungan dan masyarakat tidak merasakan dampak dari kegiatan yang dilakukan oleh yayasan pendidikan terkait, maka wajar dan dapat dibenarkan kebijakan pengenaan PBB kepada yayasan pendidikan yang diberlakukan oleh Pemerintah Kota Bandung.

Dasar penerapan pemungutan PBB-P2 bagi yayasan pendidikan bisa diwujudkan dengan didasarkan pada kewenangan diskresi yang diberikan kepada pemerintah daerah. Terkait batasan diskresi tersebut, Buku Pedoman Pengelolaan PBB-P2 yang diterbitkan oleh Kementerian Keuangan sebagai dasar bagi daerah dalam menjalankan pengalihan pajak pusat ke daerah menyebutkan bahwa kewenangan diskresi tidak hanya memberikan kewenangan bebas bagi daerah dalam menentukan tarif PBB tetapi lebih dari itu juga diberikan keleluasaan lain seperti salah satunya kewenangan untuk memberikan pembebasan atau pengurangan pajak bagi obyek pajak khusus yang ditentukan. Pemungutan PBB terhadap yayasan pendidikan tidak tepat jika disebut sebagai bagian dari diskresi pemerintah di bidang perpajakan, sebab hal yang dipersyaratkan sebagai diskresi tidak terpenuhi dibalik penerapan pemungutan PBB untuk yayasan pendidikan.

Permasalahan yang saat ini dipersoalkan adalah kriteria apa yang digunakan oleh Pemerintah Kota Bandung melalui BPPD dalam menerapkan kebijakan pengenaan dan pembebasan PBB terhadap yayasan pendidikan. Pihak BPPD Kota Bandung mengatakan bahwa dasar hukum pengenaan kebijakan pengenaan dan pembebasan PBB kepada yayasan pendidikan didasarkan pada Perda tentang Pajak Daerah, Peraturan Wali Kota Bandung tentang PBB, SOP, serta memperhatikan juga undangundang di atasnya. Dasar hukum dalam pemungutan PBB terhadap yayasan pendidikan di atas seharusnya memuat ketentuan baik dalam Perda tentang Pajak 
Daerah maupun dalam Peraturan Wali Kota Bandung tentang PBB terkait yang dapat dijadikan dasar patokan pengenaan baik berupa kriteria pengenaan, acuan penilaian pajak, maupun dasar lainnya, namun Peneliti tidak menemukan kriteria baku yang dapat dijadikan dasar dalam penerapan pemungutan PBB terhadap yayasan pendidikan.

Ketentuan sebagaimana yang diatur dalam Peraturan Wali Kota Bandung tentang pengurangan dan pembebasan PBB berpedoman pada buku pedoman pengelolaan PBBP2 yang diterbitkan oleh Dirjen Pajak, yang menyebutkan peraturan daerah dan peraturan pelaksana PBB-P2 diberikan kewenangan untuk mengatur berkaitan dengan hal: 15

1. Pemberian pengurangan, keringanan, dan pembebasan dalam hal-hal tertentu atas pokok pajak dan/atau sanksinya.

2. Tata cara penghapusan piutang pajak yang kedaluwarsa, dan/atau.

3. Asas timbal balik, berupa pemberian pengurangan, keringanan, dan pembebasan pajak kepada kedutaan, konsulat, dan perwakilan negara asing sesuai dengan kelaziman internasional.

Berdasarkan data di atas, pemerintah diberikan kewenangan bebas untuk membuat kebijakan pengenaan, pengurangan, dan bahkan pembebasan PBB-P2. Pengaturan tersebut harus dimuat dalam suatu ketentuan peraturan daerah maupun peraturan pelaksana dibawahnya.

Lahirnya peraturan daerah dan peraturan wali kota bandung tentang PBB tersebut sebagai pelaksana atas atribusi dari UU PDRD, maka jika tidak ada peraturan daerah dan peraturan wali kota, Pemerintah Kota Bandung tidak berhak memungut pajak, apalagi membuat kebijakan pengurangan dan pembebasan tanpa dasar hukum. ${ }^{16}$ Dikeluarkannya peraturan daerah dan peraturan wali kota terkait PBB menjadikan pemerintah daerah berhak dalam menentukan fasilitas apa saja yang dapat diberikan kepada wajib pajak. Upaya pengurangan dan pembebasan PBB bagi yayasan pendidikan merupakan salah satu hak yang dapat diberikan oleh pemerintah daerah kepada wajib pajak terkait.

\footnotetext{
${ }^{15} \mathrm{Ibid}$.

${ }^{16}$ Riki Rachman, Analis Pajak Kantor Badan Pengelolaan Pendapatan Daerah Kota Bandung, Wawancara Pribadi, Bandung, 26 Maret 2019.
} 
Pasal 30 Ayat (1) huruf (i) dan huruf (k) Perwal Kota Bandung tentang PBB mengatur terkait pengurangan atau penghapusan PBB, yang berbunyi:

"Wali Kota dapat memberikan pengurangan atau pembebasan pajak, dengan ketentuan sebagai berikut:

i. Objek Pajak yang dimiliki, dikuasai dan/atau dimanfaatkan oleh perguruan tinggi swasta

k. Objek Pajak yang dimiliki, dikuasai dan/atau dimanfaatkan oleh lembaga Pendidikan dasar dan menengah swasta. “

Pada Pasal 31 Ayat (8) Perwal Kota Bandung tentang PBB yang berbunyi:

“Besarnya pengurangan pajak terhadap Objek Pajak sebagaimana dimaksud dalam Pasal 30 Ayat (1) huruf I dan k, diberikan sebesar 40\% (empat puluh persen) dari besarnya pajak terutang."

Kedua ketentuan tersebut setidaknya mengindikasikan bahwa pemerintah memberikan akses keadilan bagi obyek pajak yang merasa memenuhi unsur pasal untuk dapat dibebaskan atau diberi pengurangan dalam pembayaran PBB. Pasal 77 UU PDRD bahkan memberi kesempatan bahwa perihal obyek pajak yang memenuhi kriteria yang disebutkan dalam ketentuan pasal memungkinkan untuk mendapatkan pembebasan PBB sampai $100 \%$ (seratus persen) dengan selanjutnya dinyatakan sebagai obyek fasilitas sosial atau fasilitas umum.

Peraturan Wali Kota memberikan pengurangan pajak terhadap lembaga pendidikan seperti perguruan tinggi swasta, lembaga pendidikan dasar dan menengah swasta sebesar maksimal 40\% (empat puluh persen). Peneliti berpendapat, peraturan tersebut hanya mengatur lembaga pendidikan swasta yang dapat diberikan pengurangan dan mekanisme serta persyaratan yang harus dipenuhi untuk mendapatkan pengurangan $\mathrm{PBB}$, namun tidak diatur secara jelas mengenai mekanisme dan persyaratan yang harus dipenuhi untuk bisa mendapatkan pembebasan PBB oleh lembaga pendidikan swasta. Ketidaklengkapan pengaturan tersebut kemudian menimbulkan kebingungan bagi lembaga pendidikan swasta yang ingin mengupayakan pembebasan PBB. 
Pengaturan pembebasan PBB pada Perwal Kota Bandung tentang PBB berbanding terbalik dengan ketentuan UU PDRD yang mengamini pengecualian PBB bagi suatu yayasan pendidikan yang bergerak untuk melayani kepentingan umum dan tidak untuk memperoleh keuntungan yang justru memerlukan penafsiran lebih teknis dalam pengaturan pada undang-undang dibawahnya. Dalam negara hukum, yang menempatkan asas legalitas sebagai sendi utama penyelenggaraan pemerintahan, wewenang pemerintahan itu berasal dari peraturan perundang-undangan. ${ }^{17}$ Tidak diaturnya secara jelas dalam Perwal Kota Bandung tentang PBB perihal pembebasan PBB dan kriteria pembebasan maupun pengenaan PBB akan menyebabkan Pemerintah Kota Bandung melalui BPPD rentan dalam menggunakan kewenangannya akan bertindak diluar kewenangan atau melebihi batasan kewenangan yang seharusnya.

Yayasan pendidikan untuk dapat dibebaskan atau mendapat pengurangan pajak secara konsep harus memenuhi unsur bahwa yayasan tersebut benar-benar ada bukan untuk mencari keuntungan. Yayasan merupakan bagian dari organisasi nirlaba yang memiliki maksud dan tujuan baku yang terdiri dari 3 (tiga) unsur yaitu: sosial, kemanusiaan, dan keagamaan. Selain 3 (tiga) maksud dan tujuan di atas, yayasan juga dapat melakukan kegiatan usaha dengan mendirikan badan usaha (PT) dan/atau ikut serta dalam badan usaha (PT) dengan ketentuan yang diatur dalam Undang-Undang Nomor 16 Tahun 2001 tentang Yayasan sebagaimana telah diubah dengan UndangUndang Nomor 28 Tahun 2004 tentang Perubahan Atas Undang-Undang Nomor 16 Tahun 2001 Tentang Yayasan. Merujuk pada pengertian yayasan di atas, saat ini memperlihatkan bahwa apa yang disebut Yayasan adalah suatu badan yang menjalankan usaha yang bergerak dalam segala macam badan usaha, baik yang bergerak dalam usaha yang nonkomersial maupun yang secara tidak langsung bersifat komersial.

Menyikapi problematika yayasan yang berkembang semakin kompleks saat ini, menjadi penting bagi pemerintah daerah dalam pengenaan pemungutan, pengurangan, dan pembebasan PBB-P2 untuk menentukan kriteria yang jelas dalam menentukan yayasan yang bersifat komersil maupun non komersil. Berdasarkan data yang dihimpun dari Bapak Maman Juayraman, diketahui bahwa:18

\footnotetext{
${ }^{17}$ Philipus M. Hadjon, (2005). Hukum Administrasi Negara, Yogyakarta: Gadjah Mada University Press, hlm. 139.

${ }^{18}$ Maman Juayraman. Op.Cit, 17 November 2018.
} 
“Penilaian utama bagi yayasan pendidikan sebagai penilaian keuntungan atau tidak adalah dari AD/ART yayasan dan pengelolaan keuangan di yayasan tersebut. Kedua unsur penilai yayasan tersebut berhubungan langsung dengan mekanisme pengurangan dan pembebasan yang diatur dalam Perwal Kota Bandung tentang PBB. Penilaian akan sangat bergantung dari bagaimana kroscek data lapangan yang dilakukan oleh tim teknis yang bersangkutan."

Sebagai upaya mengklarifikasi, pihak yayasan yang di wawancara penulis diantaranya yayasan pendidikan Taruna Bakti, Yayasan Istiqomah, dan Yayasan Nasional tidak merasa didatangi oleh tim teknis dan belum diadakan audit keuangan secara langsung terhadap yayasan yang bersangkutan. ${ }^{19}$

Pemaparan di atas menimbulkan sebuah pertanyaan terkait dasar pertimbangan dan kriteria yang digunakan oleh Pemerintah Kota Bandung dalam mulai menerapkan pemungutan PBB terhadap yayasan pendidikan tertentu.

Penilaian dalam kebijakan pengenaan PBB kepada yayasan yang bergerak di bidang pendidikan melalui mekanisme penilaian kesesuaian kegiatan secara praktik yang dilakukan oleh yayasan dengan AD/ART yang dimiliki yayasan, selain itu juga akan diperiksa terkait dengan akuntansi keuangan yayasan oleh tim ahli keuangan dari BPPD Kota Bandung. Penilaian kesesuaian tersebut dilakukan oleh tim teknis BPPD Kota Bandung yang dimaksudkan untuk mengetahui kegiatan yayasan diniatkan secara nyata untuk mendapatkan keuntungan atau tidak, serta kesesuaian teknis lainnya. Sementara itu dengan UU PDRD dan Perwal Kota Bandung tentang PBB serta SOP yang hanya mengatur secara limitative dasar hukum namun tidak mengatur perihal kriteria dan batasan lainnya akan membuat besar kemungkinan bagi tim teknis bertindak melampaui kewenangannya dan bertindak tanpa batasan yang jelas.

Dalam menjawab permasalahan kriteria pengenaan PBB terhadap yayasan pendidikan yang dinilai perlu ada batasan dan dasar yang jelas, penulis mendapatkan informasi dari hasil wawancara dari seorang verifikator pajak kantor BPPD Kota Bandung. Pihak BPPD Kota Bandung menetapkan kriteria penilaian melalui aspek batasan di bawah ini:

\footnotetext{
${ }^{19}$ Pihak Yayasan Pendidikan Istiqomah, Yayasan Pendidikan Taruna Bakti dan Yayasan Pendidikan Nasional, Wawancara Pribadi, Bandung, 15, 17 dan 20 November 2018.
} 
1. Penilaian AD/ART dengan kesesuaiannya dengan praktik yang dilakukan yayasan pendidikan.

2. Penilaian aspek kepentingan umum sesuai dengan frase pasal pengecualian dalam UU PDRD dan Perda Kota Bandung tentang PBB.

“Frase kepentingan umum pada yayasan pendidikan diartikan bahwa tidak ada pungutan uang kepada siswa yang dilakukan oleh yayasan. Berkegiatan untuk kepentingan umum artinya yayasan pendidikan benar-benar melakukan kegiatan untuk tujuan sosial. Pemaknaan AD/ART yayasan dalam kerangka pengelolaan keuangan adalah bagaimana yayasan mendapatkan uang untuk melaksanakan kepentingan umum. Frase kepentingan umum menghendaki bahwa uang yang diperoleh yayasan untuk pengelolaan yayasan berasal dari pengurus yayasan, sumbangan, maupun hibah. Diluar pemaknaan tersebut terkait yayasan pendidikan dalam mengelola kegiatannya tidak dikategorikan untuk melayani kepentingan umum dan berhak untuk dikategorikan sebagai wajib pajak." 20

3. Pemutakhiran data setelah adanya pengalihan pajak daerah di Kota Bandung menghasilkan suatu kesimpulan bahwa penyebab yayasan yang bergerak di bidang pendidikan dengan menetapkan iuran kepada siswa tidak dipungut pembayaran PBB yaitu, pertama tidak terdata, dan kedua berdasarkan regulasi yang mengatur sebelumnya.

4. Penilaian cashflow pemasukan dan pengeluaran yayasan

"Kriteria ini sebagai penilaian pendukung terkait kriteria di atas. Hal ini untuk mendukung penilaian kepentingan umum dan frase tidak untuk meraih keuntungan dalam ketentuan pasal pengecualian PBB dengan menilai dari sektor mana saja pemasukan yayasan dan apakah pengeluaran untuk kepentingan administratif yayasan dalam kategori wajar?". ${ }^{21}$

Pihak yayasan pendidikan dari hasil wawancara menginginkan agar Pemerintah Kota Bandung menetapkan rumusan dasar hukum secara jelas terkait pengenaan, pengurangan, dan pembebasan PBB dalam Perwal Kota Bandung tentang PBB, serta proses pengenaan, pengurangan, dan pembebasan PBB dilakukan secara transparan,

\footnotetext{
${ }^{20}$ Romi Pudji Prayoga, Verifikator Pajak Kantor Badan Pengelolaan Pendapatan Daerah Kota Bandung, Wawancara Pribadi, Bandung, 26 Maret 2019. 
adil, dan merata. Berdasarkan data yang dihimpun di atas menjadi jelas apa yang dijadikan kriteria penilaian oleh Pemerintah Kota Bandung dalam menetapkan pemungutan PBB terhadap yayasan pendidikan di Kota Bandung. Penetapan kriteria tersebut tidak berwujud tertulis baik dalam peraturan perundang-undangan maupun bentuk lainnya. Penulis menilai kriteria yang ditetapkan oleh BPPD Kota Bandung tersebut perlu untuk disebutkan dalam ketentuan Perwal Kota Bandung tentang PBB pada bagian sub bab pengurangan dan pembebasan PBB untuk mewujudkan pemungutan PBB bagi yayasan pendidikan yang transparan dan berkeadilan.

Teori kewajiban mutlak dalam hukum pajak dapat menjadi pijakan bagi Pemerintah Kota Bandung dalam upaya menyempurnakan pengaturan dalam Perwal Kota Bandung tentang PBB. Teori kewajiban mutlak mengemukakan bahwa negara sebagai groepsverband (organisasi dari golongan) dengan memperhatikan syarat keadilan, bertugas menyelenggarakan kepentingan umum, dan karenanya dapat dan harus mengambil tindakan-tindakan yang diperlukannya, termasuk juga tindakantindakan dalam lapangan pajak. ${ }^{22}$ Keputusan dan kebijakan yang dibuat di bidang perpajakan seharusnya tidak boleh mengesampingkan kepentingan umum. Perwal Kota Bandung tentang PBB harus mendasarkan pada pelayanan kepentingan umum, setelah adanya pengaturan yang jelas dan tepat, maka sudah menjadi hak negara untuk memungut dan kewajiban rakyat untuk membayar pajak yang dapat dibenarkan secara hukum.

Pelaksanaan pemungutan PBB yang dilakukan haruslah tetap menjamin keadilan bagi masyarakat, didasarkan atas pijakan aturan yang jelas, serta memperhatikan kemanfaatan bagi masyarakat. Penulis menilai secara khusus dalam hal pengurangan dan pembebasan PBB dengan mekanisme pengajuan melalui sistem kroscek yang dilakukan oleh Pemerintah Kota Bandung tetaplah dirasa perlu sebagai wujud pengefektifan basis pajak dan penyesuaian kegiatan yayasan agar tetap sesuai dengan tujuan yang terancang dalam AD/ART yayasan yang bersangkutan. Penyesuaian ini dapat dibenarkan mengingat dalam beberapa kondisi di beberapa daerah di Indonesia ditemukan kegiatan yayasan tidak berkesesuaian atau tidak sejalan dengan amanah $\mathrm{AD} / \mathrm{ART}$, bentuk kesesuaian tersebut dapat berupa suatu yayasan yang mulai meraih keuntungan di beberapa bidang usaha, yayasan yang semula dikecualikan PBB

${ }^{22}$ R. Santoso Brotodihardjo, (2013). Pengantar Ilmu Hukum Pajak, Bandung: PT Refika Aditama, hlm. 36. 
sebelumnya ternyata sudah tidak beraktivitas lagi dalam kurun waktu yang cukup lama, dan bentuk perubahan lain yang membutuhkan kesesuaian. Mengacu pada permasalahan di atas, mekanisme pelaporan dan pengajuan setiap tahun yang dilakukan oleh Pemerintah Kota Bandung bisa menjadi semacam pengawasan dari Pemerintah Kota Bandung kepada yayasan pendidikan yang ada di Kota Bandung, sekaligus menjadi pemantik bagi yayasan agar selalu berkegiatan sesuai dengan fungsi dan tujuan yang dicanangkan dalam AD/ART, walaupun demikian, hal di atas tidak serta merta membenarkan tindakan Pemerintah Kota Bandung melaksanaan pemungutan dan pembebasan PBB terhadap yayasan pendidikan tanpa didasari dengan batasan dan kriteria yang jelas dan mengikat secara hukum.

Peneliti berpendapat, pelaksanaan pemungutan PBB dan pembebasan PBB terhadap yayasan pendidikan di Kota Bandung tidak didasarkan pada batasan dan kriteria yang baku dalam bentuk tertulis dan mengikat secara hukum, seharusnya didasarkan pada rambu-rambu aturan yang jelas, bukan ditetapkan secara internal, agar terhindar dari adanya kesewenang-wenangan. Upaya pemungutan PBB sebagai pajak daerah harus didasarkan pada adanya 3 (tiga) unsur aturan prasayarat yaitu peraturan daerah, peraturan kepala daerah, dan SOP dalam hal ini di Kota Bandung biasanya diwujudkan dalam bentuk keputusan walikota.

\section{Implementasi Kebijakan dan Mekanisme Pengenaan PBB Bagi Yayasan Pendidikan di Kota Bandung}

UU Sisdiknas menghendaki keseluruhan komponen pendidikan yang ada di Indonesia harus saling terkait secara terpadu dalam mencapai tujuan pendidikan nasional. Salah satu komponen lembaga di luar pemerintahan yang terlibat dalam membantu menyukseskan pengembangan pendidikan adalah yayasan yang bergerak di bidang pendidikan.

Berdasarkan data yang dihimpun dari wawancara dengan beberapa pengurus yayasan pendidikan yang ada di Kota Bandung, yayasan pendidikan tersebut sejak kurun waktu 2016 ke belakang mendapatkan pengecualian khususnya dalam pembayaran PBB-P2 atas dasar dikategorikan Dirjen Pajak sebagai fasilitas sosial atau fasilitas umum, oleh karena sifat sosial kegiatannya, akan tetapi semenjak diterapkannya pengalihan pajak pusat ke daerah khususnya di Kota Bandung pada 
tahun 2013, beberapa yayasan pendidikan mulai dikenakan kebijakan pembayaran PBBP2 untuk obyek bumi dan bangunan yayasan pendidikan. Dasar penerapan pemungutan PBB-P2 bagi yayasan pendidikan didasarkan pada kewenangan diskresi yang diberikan kepada pemerintah daerah dalam pengalihan pajak daerah serta kewenangan untuk mengatur lebih lanjut terkait PBB yang diatur pada Pasal 66 Perda tentang Pajak Daerah melalui pengaturan dengan membentuk Perwal Kota Bandung tentang PBB yang pada implementasinya menimbulkan kontroversi dan keberatan bagi sebagian yayasan pendidikan yang merasakan ketidakadilan.

Pajak memberikan dana yang cukup besar dalam upaya pembangunan nasional, tidak terkecuali pengenaan PBB bagi yayasan pendidikan. Peneliti melakukan wawancara dengan seorang pegawai BPPD Kota Bandung yang mengatakan:23

"Pajak dan pembangunan itu keterkaitannya cukup erat. pembangunan merupakan proses yang harus didukung dengan tersedianya dana, sementara itu, pajak merupakan salah satu instrumen yang dipergunakan untuk mengumpulkan uang, kemudian uang dari hasil pemungutan pajak dipergunakan dalam pembangunan tersebut."

Kalimat yang diungkapkan oleh Bapak Maman Juayraman tersebut sejalan dengan apa yang dijelaskan dalam konsep fungsi budgeter dalam hukum pajak, yang mengatakan bahwa pajak digunakan sebagai upaya untuk memasukkan uang sebanyak-banyaknya ke dalam kas negara untuk keperluan mendorong pembangunan nasional. Fungsi regulerend dalam hukum pajak juga dapat memperkuat pernyataan di atas yang menyebutkan bahwa pengelolaan pajak sebagai apaya mendukung pembangunan diluar bidang keuangan negara.

Implementasi kebijakan baru umunya dimulai ketika para pelaku kebijakan mulai sadar bahwa adanya situasi permasalahan, hal ini senada dengan apa yang diungkapkan oleh seorang pegawai bagian pelayanan pajak BPPD Kota Bandung:24

“Kebijakan pemda mulai mengenakan pembayaran PBB kepada yayasan pendidikan karena hasil analisa tim teknis kami menyebutkan bahwa kegiatan

\footnotetext{
${ }^{23}$ Maman Juayraman, Op.Cit.

${ }^{24}$ Nia, Pegawai Bidang Pelayanan Pajak Badan Pengelolaan Pendapatan Daerah Kota Bandung, Wawancara Pribadi, Banjarmasin, 15 November 2018.
} 
yayasan pendidikan tersebut mengandung unsur meraih keuntungan diatas ratarata. Selain itu yayasan pendidikan memang mampu untuk membayar berdasarkan keuntungan yang mereka raih. Kami rasa sikap kami mengeluarkan kebijakan tersebut telah sesuai dengan apa yang diamanahkan oleh UU PDRD."

Penulis sepakat terkait dengan apa yang diungkapkan oleh Ibu Nia, UU PDRD memang telah memberikan keleluasaan kepada pemerintah daerah dalam pemungutan pajak selama pra syarat dasar hukum terpenuhi sebagaimana yang telah dilakukan oleh Pemerintah Kota Bandung. Penulis menilai setidaknya ada 2 (dua) faktor yang menjadi sorotan dalam implementasi kebijakan pengenaan pajak terhadap yayasan pendidikan di Kota Bandung. Faktor pertama yaitu terkait kurangnya komunikasi dan sosialisasi yang dilakukan oleh Pemerintah Kota Bandung sebelum dan saat pelaksanaan kebijakan dengan wajib pajak. Penyaluran komunikasi dan sosialisasi yang baik akan menghasilkan suatu proses implementasi yang baik pula, dengan adanya sosialisasi diharapkan adanya kejelasan tujuan dari implementasi kebijakan tersebut.

Aspek komunikasi juga perlu ditekankan, pelaksanaan SOP perlu dikomunikasikan terlebih dahulu dengan pihak yayasan sebagaimana yang diamanahkan oleh undang-undang diatasnya. Faktor kedua yaitu terkait informasi implementasi kebijakan, pelaksana harus mengetahui bagaimana mempraktekkan pelaksanaan kebijakan yang telah diberlakukan. Faktor ini menjadi sorotan melihat pelaksanaan kebijakan pengenaan pajak ini dilakukan terkesan dalam waktu yang singkat tanpa adanya surat pemberitahuan secara tertulis kepada pihak yayasan pendidikan sebelumnya. Kedua faktor diatas menjadi salah satu titik lemah dari implementasi kebijakan pengenaan PBB bagi yayasan pendidikan. Pemerintah daerah dalam menggunakan kewenangannya untuk memungut pajak seharusnya bisa lebih terbuka terhadap upaya penilaian pajak bagi obyek pajak dan memberikan dampak langsung yang positif yang dapat diterima oleh masyarakat. 


\section{PENUTUP}

Kriteria penerapan pemungutan PBB-P2 terhadap yayasan pendidikan di Kota Bandung tidak didasarkan pada batasan dan kriteria yang baku. Pemerintah Kota Bandung menetapkan kriteria penilaian terhadap penetapan pemungutan PBB-P2 kepada yayasan pendidikan secara internal dengan tolok ukur utama penilaian kesesuaian AD/ART dengan kondisi praktis yayasan dan penilaian laporan keuangan secara spesifik terkait bagaimana yayasan mengelola dan mendapatkan dana untuk kepentingan yayasan. Implementasi penerapan pemungutan PBB-P2 terhadap yayasan pendidikan di Kota Bandung dinilai belum maksimal disebabkan pelaksanaan pemutakhiran data yang dilakukan Pemerintah Kota Bandung khususnya terhadap yayasan pendidikan belum dilaksanakan secara menyeluruh.

Pemerintah Kota Bandung seyogyanya melakukan penyempurnaan rumusan Perwal Kota Bandung tentang PBB khususnya terkait pembebasan PBB terhadap lembaga pendidikan swasta serta kriteria baku pembebasan dan pengenaan PBB-P2 untuk lembaga pendidikan swasta. BPPD Kota Bandung seyogyanya melakukan pemutakhiran data terkait pemungutan PBB bagi yayasan pendidikan untuk mewujudkan kepastian hukum dan melaksanakan penerapan pemungutan PBB-P2 terhadap yayasan pendidikan di Kota Bandung secara konsisten, adil, dan merata dalam upaya tetap menjaga semangat yayasan pendidikan dalam pengembangan pendidikan nasional.

\section{DAFTAR PUSTAKA}

\section{Buku}

Anwar Borahima, (2000). Kedudukan Yayasan di Indonesia Eksistensi, Tujuan dan Tanggung Jawab Yayasan. Jakarta: Kencana Prenada Media Group.

Chatamarrasjid Ais, (2002). Badan Hukum Yayasan (Suatu Analisis Mengenai Yayasan Sebagi Suatu Badan Hukum Sosial), Bandung: PT. Citra Aditya Bakti.

Gunadi, (1995). Peranan Pemeriksaan dan Penyidikan di Era Refromasi dalam Reformasi Perpajakan di Indonesia, Jakarta: Yapnindo.

Philipus M. Hadjon, (2005). Hukum Administrasi Negara, Yogyakarta: Gadjah Mada University Press. 
R. Santoso Brotodihardjo, (2013). Pengantar Ilmu Hukum Pajak, Bandung: PT Refika Aditama.

Rochmat Soemitro, (1993). Hukum Perseroan Terbatas, Yayasan dan Wakaf, Bandung: PT. Eresco. (1994). Asas dan Dasar Perpajakan, Bandung: Refika Aditama.

Ronny Hanitjo Soemitro, (1990). Metodologi Penelitian Hukum dan Jurimetri, Jakarta: Ghalia Indonesia.

Soerjono Soekanto, (2014). Pengantar Penelitian Hukum, Jakarta: Penerbit Universitas Indonesia (UI-Press).

Sophar Lumbantoruan, (1997). Administrasi Perpajakan, Jakarta: Sinar Harapan.

Y. Sri Pudyatmoko, (2008). Pengantar Hukum Pajak, Yogyakarta: CV. Andi Offset.

\section{Jurnal}

Janpatar Simamora, (2014) “Tafsir Makna Negara Hukum dalam Perspektif UUD RI 1945", Jurnal Dinamika Hukum, Vol. 14, No. 3.

Machfud Sidik, (2004). “Prospek dan Problematika Pelaksanaan UU No. 25/1999 Tentang Perimbangan Keuangan Pusat-Daerah", Jurnal Hukum Bisnis, Vol. 23, No. 1 .

\section{Peraturan Perundang-Undangan}

Undang-Undang Dasar Negara Republik Indonesia Tahun 1945.

Undang-Undang Nomor 16 Tahun 2001 tentang Yayasan.

Undang-Undang Nomor 20 Tahun 2003 tentang Sistem Pendidikan Nasional.

Undang-Undang Nomor 28 Tahun 2004 tentang Perubahan Atas Undang-Undang Nomor 16 Tahun 2001 tentang Yayasan.

Undang-Undang Nomor 28 Tahun 2009 tentang Pajak dan Retribusi Daerah.

Undang-Undang Nomor 23 Tahun 2014 tentang Pemerintahan Daerah.

Peraturan Bersama Menteri Keuangan dan Menteri Dalam Negeri Nomor 15/Pmk.07/2014 Nomor 10 Tahun 2014 tentang Tahapan Persiapan dan Pelaksanaan Pengalihan Pajak Bumi dan Bangunan Perdesaan dan Perkotaan Sebagai Pajak Daerah. 
Peraturan Direktur Jenderal Pajak Nomor PER-61/PJ/2010 tentang Tata Cara Persiapan Pengalihan Pajak Bumi dan Bangunan Perdesaan dan Perkotaan sebagai Pajak Daerah.

Peraturan Daerah Kota Bandung Nomor 20 Tahun 2011 tentang Pajak Daerah.

Peraturan Daerah Kota Bandung Nomor 06 Tahun 2016 tentang Perubahan Atas Peraturan Daerah Kota Bandung Nomor 20 Tahun 2011 tentang Pajak Daerah.

Peraturan Walikota Bandung Nomor 1405 Tahun 2016 tentang Kedudukan, Susunan Organisasi, Tugas, dan Fungsi serta Tata Kerja Badan Pengelolaan Pendapatan Daerah Kota Bandung.

Peraturan Wali Kota Bandung Nomor 244 Tahun 2017 tentang Petunjuk Teknis dan Tata Cara Pemungutan Pajak Bumi dan Bangunan.

\section{Sumber Lain}

Direktorat Jenderal Pajak Kementerian Keuangan (2014), Buku Pedoman Pengelolaan Pengalihan PBB P2, diakses pada tanggal 18 November 2018. https://www.kemenkeu.go.id/sites/default/files/pedoman_umum_pengelolaan_pb b_p2.pdf. 